\title{
ROBOTY DODATKOWE W KOLEJOWYCH PRZEDSIĘWZIĘCIACH BUDOWLANYCH
}

\author{
Agnieszka Leśniak ${ }^{\bowtie}$, Filip Janowiec \\ Wydział Inżynierii Lądowej, Politechnika Krakowska, Kraków
}

\begin{abstract}
STRESZCZENIE
Celem pracy jest analiza specyfiki występowania robót dodatkowych w kolejowych przedsięwzięciach budowlanych, realizowanych obecnie na terenie Polski. W artykule przedstawiono kluczowe elementy robót dodatkowych: definicję zjawiska, czynniki powodujące ich występowanie, sposób implementacji dodatkowych prac do umowy podstawowej oraz spodziewane konsekwencje robót dodatkowych. Omówiono najważniejsze uwarunkowania prawne, obejmujące nowelizację ustawy Prawo zamówień publicznych z 2016 roku. Autorzy zaprezentowali propozycje schematów zgłaszania robót dodatkowych w najczęściej występujących typach realizacji inwestycji w zależności od stosowanego wzoru umownego.
\end{abstract}

Słowa kluczowe: roboty dodatkowe, inwestycje kolejowe, zamówienia publiczne

\section{WSTĘP}

Realizacja inwestycji budowlanych jest procesem złożonym, składającym się z licznych etapów (Połoński, 2008). Podczas każdego z nich można wyodrębnić wiele nieprzewidzianych zdarzeń mogących wpłynąć na podstawowe parametry każdego przedsięwzięcia budowlanego: koszt, czas, jakość i zakres. Doświadczony wykonawca powinien być przygotowany na niespodziewane sytuacje i kalkulować ryzyko już na etapie składania oferty. W literaturze można odnaleźć wiele prac, w których autorzy analizują i poszukają optymalnych rozwiązań w zakresie organizacji przedsięwzięć budowlanych (Hoła, 2015; Grzyl, Miszewska-Urbańska i Apollo, 2017; Lendo-Siwicka, Pawluk, Żerek i Trach, 2018), planowania w czasie (Krzemiński, 2017;
Leśniak, Piskorz, Spišáková i Mačková, 2018), bezpieczeństwa pracy (Hoła i Szóstak, 2015), kosztów (Juszczyk, Leśniak i Zima, 2018; Leśniak i Juszczyk, 2018), planowania logistyki (Sobotka i Czarnigowska, 2005) czy też stosowania innowacyjnych rozwiązań (Kapliński, 2018). Podejmowane działania zamierzające do zakończenia robót budowlanych z sukcesem powinny redukować ryzyko (Gładysz, Kuchta, Skorupka i Duchaczek, 2015; Plebankiewicz, Zima i Wieczorek, 2016; Kaczorek, Krzemiński i Ibadov, 2017; Kowalski i Połoński, 2018). Niezależnie od proponowanych metod zapobiegania ryzyku i niespodziewanym zdarzeniom na budowie nie da się ich całkowicie wyeliminować (Czemplik, 2003). Zaliczyć tu można konieczność realizacji 
robót dodatkowych, czyli robót nieobjętych umową podstawową. Roboty dodatkowe występują w wielu przedsięwzięciach i wynikają $\mathrm{z}$ potrzeby dostosowania zaistniałej sytuacji na budowie do oczekiwań inwestora, zgodnych z obowiązującymi przepisami i wiedzą techniczną (Czemplik, 2012).

Rozwój infrastruktury transportowej jest ściśle powiązany $\mathrm{z}$ modernizacją lub budową nowych dróg i linii kolejowych. W Polsce wraz z przystąpieniem do Unii Europejskiej w 2004 roku przyjęty został plan dostosowania krajowej sieci drogowej oraz kolejowej do standardów wspólnotowych (Ministerstwo Infrastruktury, 2008). Strategia unifikacji infrastruktury objęła zarówno adaptację przepisów prawnych do norm unijnych, jak i przystosowanie techniczne obiektów budowlanych wchodzących w skład najważniejszych ciaggów komunikacyjnych - dróg kołowych oraz linii kolejowych. Szczególną rolę w kształtowaniu polityki transportowej UE odgrywa transport kolejowy, który zgodnie z założeniami najważniejszych strategii unijnych powinien stanowić dopełnienie oraz odciążenie sieci drogowej (Uchwała nr 219/2011 Rady Ministrów, 2011). Obecnie realizowany jest największy program modernizacji linii kolejowych w Polsce - tzw. Krajowy Program Kolejowy (KPK) do 2023 roku. Szacowany budżet zakłada około 66 mld zł, które zostana przeznaczone na wykonanie budowlanych inwestycji kolejowych w 4 kluczowych sektorach, efektem czego będzie modernizacja około 9 tys. km linii kolejowych (Uchwała nr 186/2017 Rady Ministrów, 2017). Biorąc pod uwagę rozmiary inwestycji, jest to jeden z najbardziej prawdopodobnych obszarów, w których ilość robót dodatkowych może w sposób znaczący wpłynąć na koszt i czas zaplanowanych inwestycji.

W niniejszym artykule autorzy scharakteryzują sposób postępowania w przypadku wystąpienia robót dodatkowych w kolejowych przedsięwzięciach budowlanych $\mathrm{z}$ uwzględnieniem ich merytorycznej weryfikacji, finansowania oraz implementacji na podstawie obowiązujących przepisów prawnych. Omówiony zostanie wpływ znowelizowanej ustawy Prawo zamówień publicznych z 2016 roku, która zmieniła dotychczasowy sposób sankcjonowania robót dodatkowych w umowie podstawowej.

\section{ROBOTY DODATKOWE}

\section{Definicja i charakterystyka robót dodatkowych}

Pojęcie robót dodatkowych jest powszechnie używane przez uczestników procesu budowlanego w Polsce, jednak nie ma ono bezpośredniego umocowania w obowiązujących przepisach prawa. Funkcjonuje jako interpretacja terminu prace dodatkowe opisanego w Kodeksie cywilnym (kc) z 1964 roku. Zgodnie z art. $630 \S 1 \mathrm{kc}$ pracami dodatkowymi nazywa się takie prace, które pojawiły się $\mathrm{w}$ trakcie realizacji dzieła, a nie były przewidziane $\mathrm{w}$ zestawieniu prac planowanych, będących podstawą obliczenia kosztorysowego. Zgodnie z pozostałą wykładnią za prace dodatkowe przyjmujący zamówienie może żądać podwyższenia umówionego wynagrodzenia (Juszczyk, Leśniak i Zima, 2013).

Przyczyny wystąpienia robót dodatkowych są uzależnione od wielu czynników pojawiających się podczas realizacji inwestycji budowlanych. Część z nich wynika z uwarunkowań prawnych, czynników zewnętrznych zakłócających proces budowlany czy też zmian wprowadzanych przez poszczególnych uczestników procesu budowlanego. Czynniki te mogą również pojawić się na każdym z etapów realizacji inwestycji budowlanych, a dołożenie należytej staranności przy sporządzaniu dokumentacji projektowej nie gwarantuje ich wyeliminowania.

Dotychczasowe próby identyfikacji oraz kwantyfikacji przyczyn wystąpienia robót dodatkowych wskazują, iż część czynników jest wspólna dla każdego typu przedsięwzięć budowlanych. Do najczęściej występujących zalicza się: błędy projektowe, błędne rozpoznanie warunków gruntowych, przyczyny administracyjne, warunki pogodowe lub przyczyny leżące po stronie inwestora (Czemplik, 2012). Przyczyny powodujące roboty dodatkowe związane są $z$ etapem projektowania oraz budowy. W tabeli 1 przedstawiono przykładowe czynniki wystąpienia robót dodatkowych na etapie projektowania oraz budowy.

Roboty dodatkowe mają negatywny wpływ na realizowaną inwestycję. Najczęściej powodują niespodziewany wzrost kosztów dla inwestora oraz w sposób znaczny mogą wpłynąć na wydłużenie prac budowlanych realizowanych przez wykonawcę robót. To z ko- 
Tabela 1. Przykładowe czynniki wystąpienia robót dodatkowych na etapie projektowania oraz budowy

Table 1. Examples of additional work occurrences at the design and construction stages

\begin{tabular}{|c|c|}
\hline \multicolumn{2}{|c|}{ Etap wystąpienia czynników - Stage of occurrence of factors } \\
\hline prace projektowe - designing works & budowlane - construction works \\
\hline $\begin{array}{l}\text { - nieujawnione na dostępnych mapach terenu } \\
\text { (budowy elementy infrastruktury podziemnej) } \\
\text { elements of construction site not disclosed } \\
\text { on available maps (elements of underground } \\
\text { infrastructure) } \\
\text { - niepełne rozpoznanie geologiczno-inżynier- } \\
\text { skie budowy } \\
\text { incomplete geological and engineering } \\
\text { recognition of the construction site } \\
\text { - błędy merytoryczne i niekompletność } \\
\text { dokumentacji projektowej } \\
\text { factual errors and incompleteness of project } \\
\text { documentation }\end{array}$ & $\begin{array}{l}\text { - opóźnienia dostaw materiałów i wyrobów budowlanych przez dostawców } \\
\text { delays in the supply of materials and construction products by suppliers } \\
\text { - zła organizacja robót } \\
\text { bad organization of works } \\
\text { - zmiany rozwiązań projektowych wprowadzane przez inwestora } \\
\text { changes in design solutions introduced by the investor } \\
\text { - nieudzielanie zamknięć torowych pomimo dopełnienia warunków } \\
\text { umownych } \\
\text { failure to provide track closures despite the fulfillment of contractual terms } \\
\text { - problemy na sąsiadujących inwestycjach (tzw. styki kontraktów) } \\
\text { problems on neighboring investments (so-called contract contacts) }\end{array}$ \\
\hline
\end{tabular}

lei rodzi obawy dalszych konsekwencji oraz powoduje ryzyko wystąpienia konfliktów między uczestnikami procesu budowlanego (Czemplik, 2012).

\section{Regulacje prawne w zakresie zlecania robót dodatkowych}

Roboty budowlane, w szczególności roboty sektorowe, zlecane są najczęściej przez podmiot publiczny posiadający finansowanie ze środków budżetu państwa (zarząd dróg, zarząd kolei itp.). Podstawowym przepisem prawnym regulującym postępowanie w przypadku zamawiania robót budowlanych oraz usług obejmujących dostawy przez inwestorów publicznych jest ustawa Prawo zamówień publicznych (Pzp) z 2004 roku. Zapisy ustawy normują proces - począwszy od etapu przygotowania postępowania przetargowego, poprzez wyłonienie wykonawcy, aż do momentu rozliczenia umowy przez inwestora. Ustawa porządkuje również kwestię implementacji robót dodatkowych do treści umowy podstawowej.

Dotychczasowe zapisy ustawy pozwalały na zlecanie robót dodatkowych w postaci zamówienia dodatkowego bądź zamówienia uzupełniającego w try- bie zamówienia $\mathrm{z}$ wolnej ręki. Spełnienie przesłanek umożliwiających zastosowanie tego trybu było ściśle powiązane ze specyfiką wystapienia robót dodatkowych (m.in. nieprzewidywalność zamówienia, wykonanie robót budowlanych w okresie zamówienia podstawowego). Szczegółowy opis procedury zawierały art. 67 oraz 144 ustawy Pzp. Ponadto wykonawca musiał potwierdzić możliwość wykonania robót dodatkowych, a inwestor musiał zadeklarować gotowość do zapłaty za dodatkowe zlecenie. Formalizacja tego procesu odbywała się poprzez tzw. protokół konieczności lub stanowiła aneks do umowy podstawowej.

Nowelizacja Prawa zamówień publicznych z 2016 roku uchyla możliwość stosowania zamówienia dodatkowego $\mathrm{w}$ trybie $\mathrm{z}$ wolnej ręki (poza pewnymi wyjątkami) oraz usuwa trwale pojęcie zamówienia uzupełniającego. Zapisy ustawy uniemożliwiają również wprowadzanie zamówienia dodatkowego odrębnym zamówieniem. Zlikwidowany termin zamówienie uzupełniające został zastąpiony nowym - powtórzenie podobnych usług lub robót budowlanych, co w zamyśle ustawodawcy powinno precyzować sankcjonowanie robót dodatkowych w umowie podstawowej. 
Dodatkowo ustawodawca przewidział szczególny tryb postępowania dla robót sektorowych opisanych w art. 134, który umożliwia stosowanie dotychczasowych przepisów dla wyszczególnionych branż, m.in. budownictwa kolejowego.

\section{INWESTYCJE KOLEJOWE W POLSCE}

Infrastruktura kolejowa w Polsce znajduje się pod zarządem kilkunastu podmiotów gospodarczych, jednak największa jej część, około 96\%, jest w posiadaniu Narodowego Zarządcy Linii Kolejowych - Spółki PKP Polskie Linie Kolejowe S.A. (PKP, 2017a). Do najważniejszych zadań statutowych spółki należy dbanie o istniejącą infrastrukturę, w tym przeprowadzanie inwestycji budowlanych na narodowej sieci kolejowej (PKP, 2017b). Spektrum działań zarządcy obejmuje zarówno bieżące naprawy oraz konserwacje, jak i złożone przedsięwzięcia budowlane, takie jak: rewitalizacje, modernizacje czy też budowę nowych linii kolejowych.

Wejście Polski do UE umożliwiło spółce PKP PLK S.A. ubieganie się o dofinansowanie budowlanych projektów kolejowych ze środków wspólnotowych. Głównym celem finansowania jest dostosowanie infrastruktury (w tym kolejowej) państw członkowskich UE do podobnego poziomu technicznego. Dodatkowo wielkość udzielonego dofinansowania środkami unijnymi zależy od wielu czynników, w tym rozmiaru wkładu własnego państwa będącego beneficjentem dotacji.

W celu uzyskania maksymalnie dużych, a jednocześnie możliwych do efektywnego wydatkowania środków skrupulatnie była budowana polityka transportowa państwa, zakładająca etapowe realizowanie inwestycji budowlanych na sieci kolejowej w Polsce. Zarząd PKP PLK S.A. wraz z Ministerstwem Infrastruktury opracował wiele dokumentów pozwalających na wdrożenie kluczowych inwestycji. Wyznaczyły one zakres rzeczowy oraz ilościowy modernizowanej infrastruktury przez ostatnie lata. Obecnie trwajacca perspektywa unijna „Krajowy Program Kolejowy do roku 2023" zakłada realizację kilkuset projektów na rekordową kwotę 66 mld zł (Uchwała nr 186/2017 Rady Ministrów, 2017). Lista zaplanowanych do wykonania zadań została przedstawiona na rysunku 1.

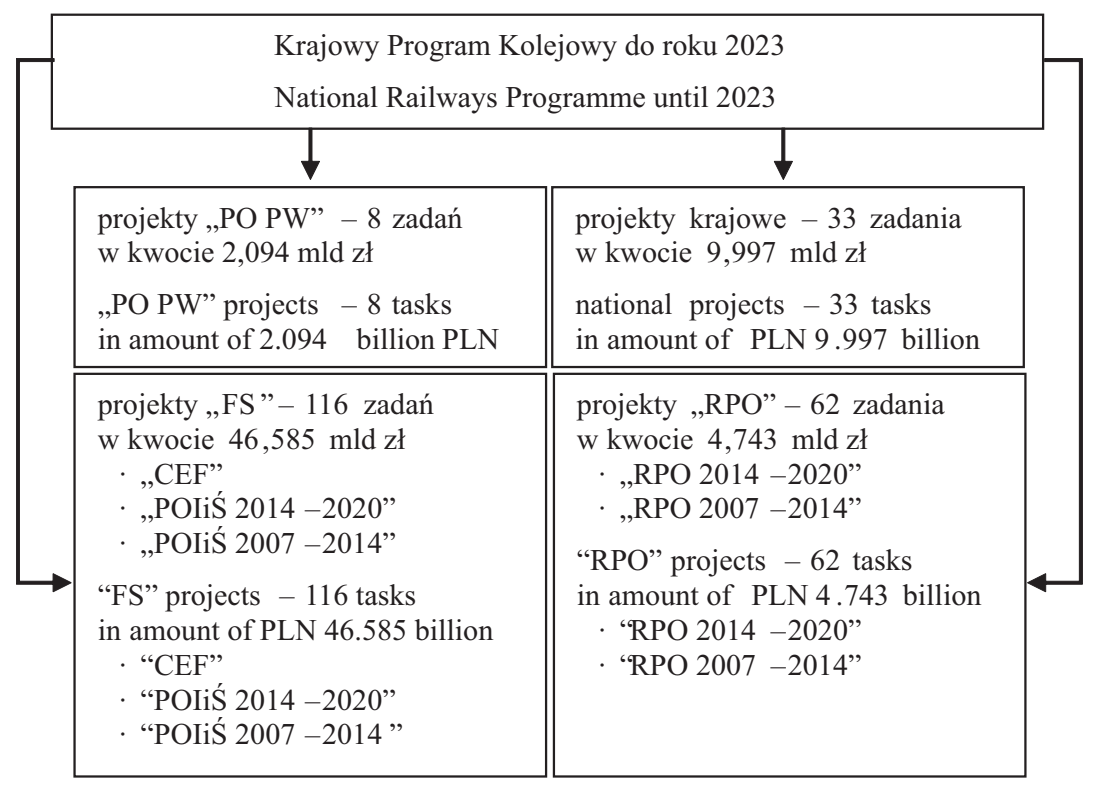

Rys. 1. Lista zadań inwestycyjnych planowanych w ramach Krajowego Programu Kolejowego (Uchwała nr 186/2017 Rady Ministrów, 2017)

Fig. 1. A list of investment tasks planned under the National Railway Programme (Resolution No 186/2017 of the Council of Ministers, 2017) 
Zakwalifikowanie zadań inwestycyjnych do poszczególnych kategorii definiuje rodzaj umowy obowiązującej podczas wykonywania robót budowlanych i/lub projektowych. W przypadku projektów „unijnych" stosowanym standardem umowy są warunki kontraktowe Fédération Internationale Des Ingénieurs Conseils - FIDIC (Boczek, 2015). Pozostałe projekty objęte KPK nie narzucają wybranego wzoru kontraktowego, jednak zamawiający stara się ujednolicać wzory umów, wprowadzając zapisy analogiczne jak te występujące we wzorach kontraktów FIDIC.

\section{ROBOTY DODATKOWE W INWESTYCJACH KOLEJOWYCH}

\section{Schemat działania}

Występowanie robót dodatkowych jest zjawiskiem losowym, którego prawdopodobieństwo może być zdeterminowane przez wiele czynników. Niezależnie od przyczyn powstania robót dodatkowych sposób postępowania oraz reakcji na ich występowanie jest zbliżony i składa się z kilku etapów, scharakteryzowanych przez autorów w tabeli 2 .

Tabela 2. Etapy postępowania w przypadku zaistnienia robót dodatkowych

Table 2. Stages of conduct in the event of additional works

\begin{tabular}{|c|c|}
\hline $\begin{array}{l}\text { Nazwa etapu } \\
\text { The name of a stage }\end{array}$ & $\begin{array}{l}\text { Charakterystyka etapu } \\
\text { Characteristics of the stage }\end{array}$ \\
\hline $\begin{array}{l}\text { Zaistnienie czynnika } \\
\text { inicjującego roboty } \\
\text { dodatkowe }\end{array}$ & $\begin{array}{l}\text { Wykrycie zjawiska, które w ramach swoich następstw może powodować niezaplanowane prace nieujęte } \\
\text { przy sporządzaniu umownego zakresu robót. Zdarzenia nieprzewidziane można zaklasyfikować do } \\
\text { dwóch grup: wykryte podczas prac projektowych oraz ujawnione podczas robót budowlanych }\end{array}$ \\
\hline $\begin{array}{l}\text { The existence of } \\
\text { a factor initiating } \\
\text { additional work }\end{array}$ & $\begin{array}{l}\text { Detection of a phenomenon which, as a result of its consequences, may cause unplanned work, not } \\
\text { included in the preparation of a contractual scope of works. Unforeseen events can be classified into two } \\
\text { groups: detected during design works, disclosed during construction works }\end{array}$ \\
\hline $\begin{array}{l}\text { Działania } \\
\text { zapobiegawcze }\end{array}$ & $\begin{array}{l}\text { Ograniczenie skutków niepożądanych, wynikających z pojawienia się czynnika powodującego roboty } \\
\text { dodatkowe, np.: zabezpieczenie zniszczonej instalacji podziemnej, która nie mogła być zidentyfikowana } \\
\text { na skutek błędnie sporządzonej dokumentacji projektowej }\end{array}$ \\
\hline Preventive actions & $\begin{array}{l}\text { Limitation of undesirable effects resulting from the appearance of a factor causing additional works, e.g. } \\
\text { protection of a damaged underground installation, which could not be identified due to incorrect project } \\
\text { documentation }\end{array}$ \\
\hline $\begin{array}{l}\text { Weryfikacja } \\
\text { zasadności robót } \\
\text { dodatkowych }\end{array}$ & $\begin{array}{l}\text { Przegląd warunków umownych, przepisów prawa oraz pozostałej dokumentacji kontraktowej mającej } \\
\text { na celu jednoznaczne określenie strony winnej powstania robót dodatkowych (wykonawca lub inwestor) } \\
\text { wraz ze wskazaniem czynnika ich wystąpienia }\end{array}$ \\
\hline $\begin{array}{l}\text { Verification of the } \\
\text { validity of additional } \\
\text { works }\end{array}$ & $\begin{array}{l}\text { Review of contractual terms, legal regulations and other contract documentation aimed at clearly identi- } \\
\text { fying the party guilty of creating additional works (contractor or investor) together with an indication of } \\
\text { their occurrence }\end{array}$ \\
\hline $\begin{array}{l}\text { Określenie zakresu } \\
\text { oraz typu robót } \\
\text { dodatkowych }\end{array}$ & $\begin{array}{l}\text { Zaproponowanie rozwiązania projektowego lub dobór technologii wykonywania robót budowlanych } \\
\text { związanych z wystąpieniem prac nieujętych umową. Wykonanie obmiaru dodatkowych robót, opraco- } \\
\text { wanie ich kosztorysu oraz stworzenie harmonogramu uwzględniającego wpływ robót dodatkowych na } \\
\text { czas trwania inwestycji }\end{array}$ \\
\hline $\begin{array}{l}\text { Determination of the } \\
\text { scope and type of } \\
\text { additional works }\end{array}$ & $\begin{array}{l}\text { Proposing a design solution or selection of technology for carrying out construction works related to } \\
\text { the occurrence of works not included in the contract. Execution of additional works, preparation of their } \\
\text { cost estimate and creation of a schedule including the impact on the duration of the investment }\end{array}$ \\
\hline $\begin{array}{l}\text { Zlecenie robót } \\
\text { dodatkowych }\end{array}$ & $\begin{array}{l}\text { Polecenie dotychczasowemu wykonawcy wykonanie robót dodatkowych (wraz z dodatkowym } \\
\text { wynagrodzeniem) bądź przeprowadzenie oddzielnego postępowania w celu wyłonienia nowego } \\
\text { wykonawcy na dodatkowy zakres prac }\end{array}$ \\
\hline $\begin{array}{l}\text { Additional works } \\
\text { order }\end{array}$ & $\begin{array}{l}\text { The order of the previous contractor to perform additional works (along with additional remuneration), } \\
\text { or to conduct separate proceedings in order to select a new contractor for an additional scope of works }\end{array}$ \\
\hline
\end{tabular}


Tryb reakcji na pojawiające się roboty dodatkowe jest ściśle powiązany z charakterystyką danego przedsięwzięcia budowlanego, obejmującego indywidualne cechy każdej inwestycji. Jednym z ważniejszych elementów związanych z robotami dodatkowymi w projektach objętych KPK jest sposób ich implementacji do umowy. Wprowadzenie nieprzewidzianych robót do zapisów umownych związane jest $\mathrm{z}$ typem zastosowanej umowy. Schemat ideowy wprowadzania robót dodatkowych występujących podczas realizacji inwestycji kolejowych objętych KPK został przedstawiony na rysunku 2.

\section{Projekty współfinansowane ze środków Unii Europejskiej}

Inwestycje kolejowe finansowane ze środków unijnych stanowią ponad $70 \%$ budżetu przewidzianego w ramach KPK (Uchwała nr 186/2017 Rady Ministrów, 2017). Wydatkowanie tych funduszy wiąże się z przestrzeganiem zapisów warunków ogólnych FIDIC oraz warunków szczególnych. Warunki szczególne są modyfikacją zapisów warunków ogólnych i uzupełniają, zmieniają, wprowadzają dodatkowe klauzule, aby jednoznacznie sprecyzować obowiązki i uprawnienia stron, wprowadzić zmiany, które zamawiający zdecydował się włączyć, a także zdefiniować niektóre określenia lub nadać im odpowiednie znaczenie. Oprócz tworzenia istotnych postanowień umownych warunki szczególne przedstawiają procedury i sposób działania stron umowy podczas nieprzewidzianych zdarzeń $\mathrm{w}$ trakcie realizacji prac. Do jednego z nich zalicza się procedura działania stron kontraktu w przypadku pojawienia się robót dodatkowych. Proces ten jest szczegółowo opisany w klauzuli 13 ,Zmiany i korekty”. Zmiany pojawiające się podczas realizacji prac mogą być inicjowane przez jedną ze stron kontraktowych: zamawiającego, inżyniera kontraktu lub wykonawcę. Najczęściej sa jednak zgłaszane przez wykonawcę, na którym to spoczywa obowiązek realizacji prac budowlanych. Schemat graficzny procedury zgłaszania i wprowadzania robót dodatkowych został przedstawiony na rysunku 3.

\section{Projekty pozostałe (niewspółfinansowane ze środków Unii Europejskiej)}

Inwestycje, które nie są współfinansowane ze środków unijnych, nie są zazwyczaj realizowane według wzorów kontraktów FIDIC. Zamawiający sporządza umowę, posiłkując się swoim dotychczasowym doświadczeniem, uwzględniając bieżace uwarunkowania prawne oraz wzorując się na istniejących standardach. Przegląd dokumentacji SIWZ nowo ogłaszanych postępowań przetargowych wskazuje, iż zamawiający często wzoruje się na zapisach pochodzących z umów FIDIC, wobec czego procedura sankcjonowania robót

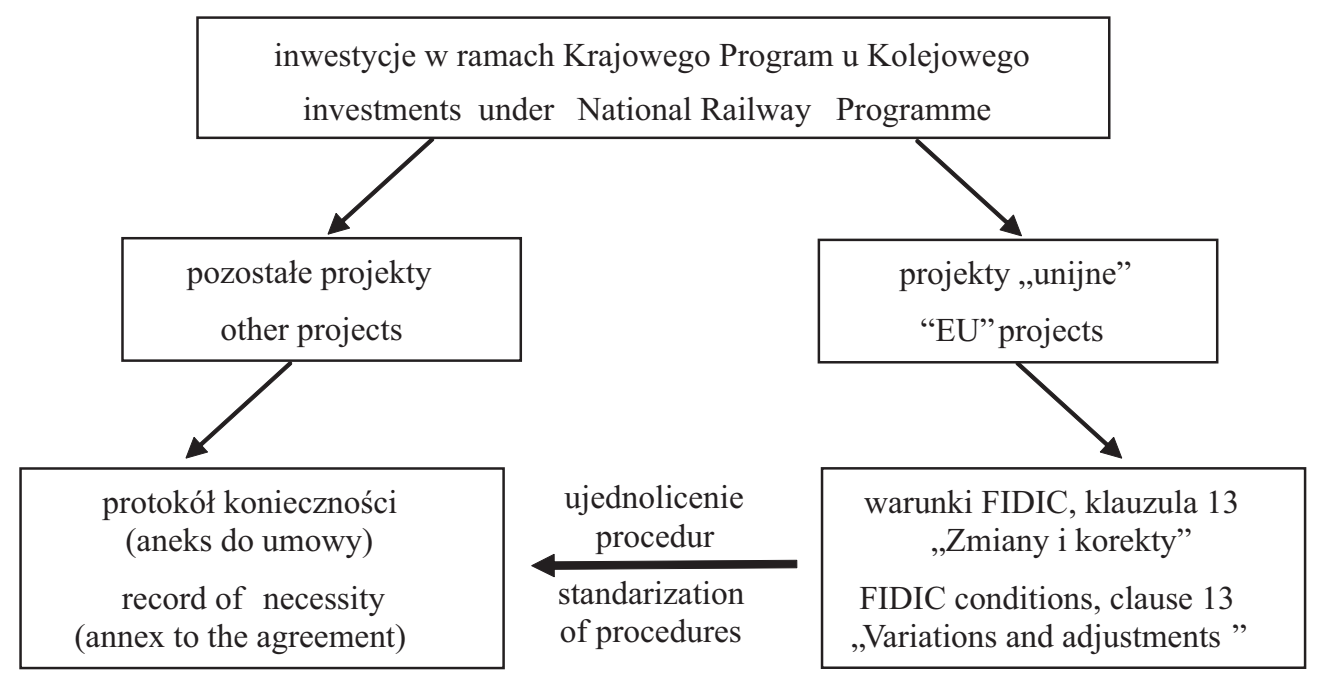

Rys. 2. Schemat implementacji robót dodatkowych w inwestycjach objętych Krajowym Programem Kolejowym

Fig. 2. Diagram of implementation of additional works in investments covered by the National Railway Programme 


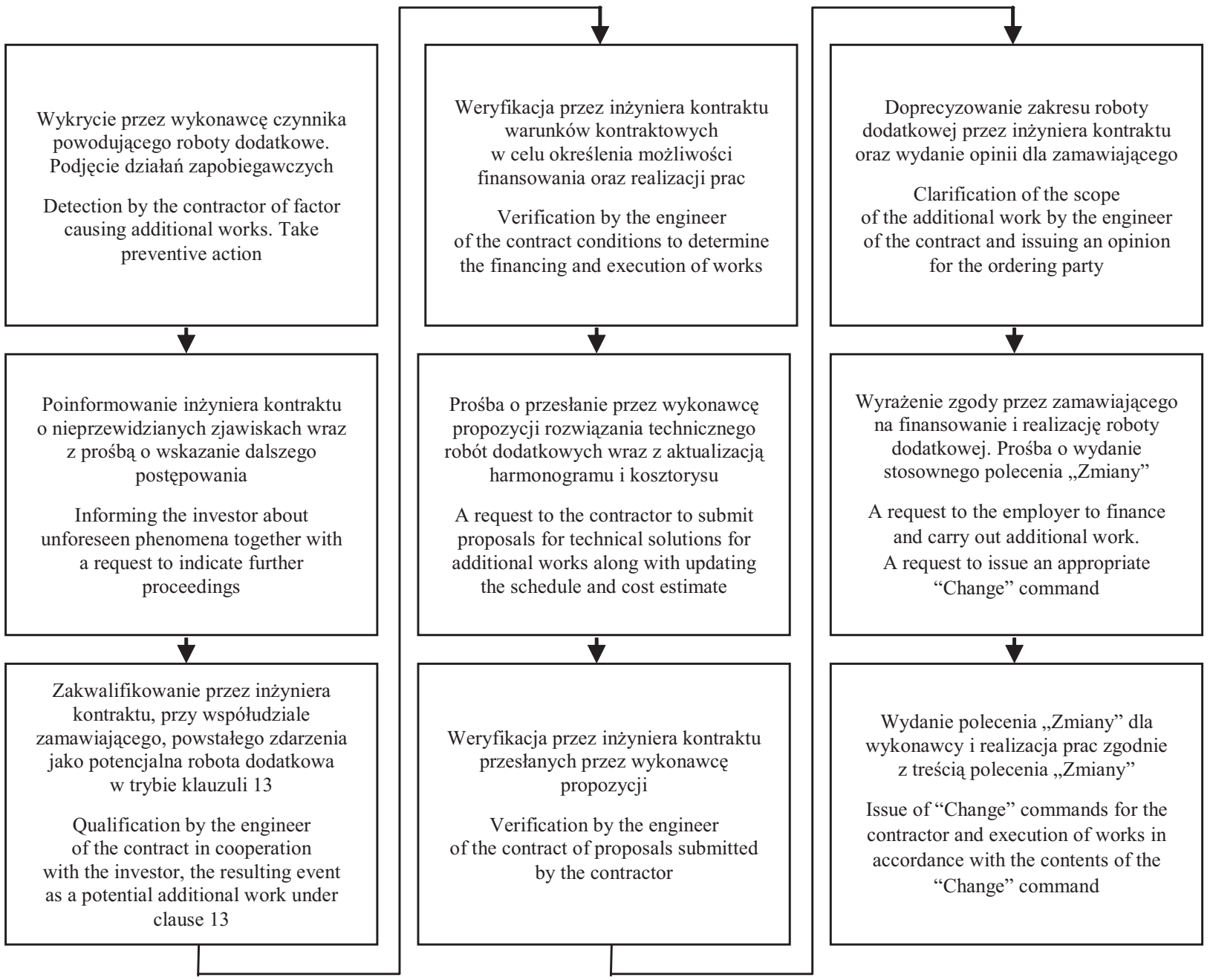

Rys. 3. Schemat zgłaszania robót dodatkowych przez wykonawcę według warunków FIDIC

Fig. 3. Schedule for reporting additional works by the contractor according to the FIDIC conditions

dodatkowych jest zbliżona do tej opisanej w klauzuli 13 warunków FIDIC.

Główną różnicą występującą przy zgłaszaniu robót dodatkowych między procedurą FIDIC a warunkami w pozostałych projektach w ramach KPK jest brak zewnętrznego nadzoru w postaci inżyniera kontraktu/ /projektu. Obowiązki inżyniera kontraktu muszą zostać scedowane na innego uczestnika procesu budowlanego bądź przedstawiciela personelu zamawiającego. Jednym ze stosowanych rozwiązań jest delegowanie kompetencji na inspektora nadzoru wiodącej branży lub naczelnika/specjalistę odpowiedniego działu zamawiającego.
Kolejną zmianą wyróżniającą proces implementacji robót dodatkowych w pozostałych projektach w ramach KPK jest krótsza ścieżka administracyjna. Brak konieczności stosowania zapisów klauzuli 13 warunków FIDIC redukuje wnioski wykonawcy oraz proces formalny. Nie jest wymagane stosowanie procedury polecenia w formie zbliżonej do polecenia „Zmiany” ani jego składowych (opinii inżyniera kontraktu itp.).

Na podstawie doświadczeń zawodowych autorów można stwierdzić, iż kwestią wieńczącą sankcjonowanie robót dodatkowych $\mathrm{w}$ pozostałych projektach w ramach KPK jest stworzenie tzw. protokołu konieczności. Dokument zawiera podobne dane jak 
polecenie „Zmiany”. Do najważniejszych z nich można zaliczyć: podstawę prawną robót dodatkowych, opinię techniczną przyjętego rozwiązania, kosztorys na roboty dodatkowe, harmonogram prac dodatkowych, finansowanie oraz zgodę zamawiającego na realizację. Finalizacja wprowadzenia robót dodatkowych związana jest $\mathrm{z}$ włączeniem treści protokołu konieczności do umowy za pomocą stosownego aneksu. Autorzy proponują schemat zgłaszania robót dodatkowych przez wykonawce w projektach pozostałych ujętych w ramach KPK (rys. 4).

\section{Finansowanie robót dodatkowych}

Każda robota dodatkowa wprowadzana do realizowanej inwestycji budowlanej wymaga odpowiedniego zabezpieczenia finansowego. Zamawiający ma kilka sposobów zabezpieczenia odpowiedniej ilości kapitału i stosuje je w zależności od bieżących potrzeb oraz uwarunkowań. W przypadku inwestycji realizowanych w ramach KPK zaliczają się do nich:

- rezerwa powstała na skutek mniejszej ceny ofertowej złożonej w postępowaniu przetargowym niż szacowany budżet inwestorski przewidziany na wykonanie projektu;

- stosowanie tzw. kwoty warunkowej, która stanowi część kosztorysu ofertowego i jest przewidziana na różne przedsięwzięcia $\mathrm{w}$ ramach realizowanych prac (komunikacja zastępcza, roboty dodatkowe itp.);

- dodatkowe finansowanie ze środków unijnych, które zamawiający może pozyskać $\mathrm{w}$ przypadku spełnienia odpowiednich warunków;

- finansowanie ze środków spółki PKP PLK S.A. uzyskane poprzez różne działania, m.in.: zaciągnięcie kredytów czy emisję dodatkowych akcji.

\section{PODSUMOWANIE}

Prawidłowe przygotowanie wykonawcy do realizacji inwestycji wiąże się z właściwym oszacowaniem ryzyka mogącego pojawić się podczas prac projektowych oraz budowy. Jednym $z$ elementów wymagającym poprawnego ocenienia jest ryzyko wystąienia robót dodatkowych. W artykule wskazano czynniki

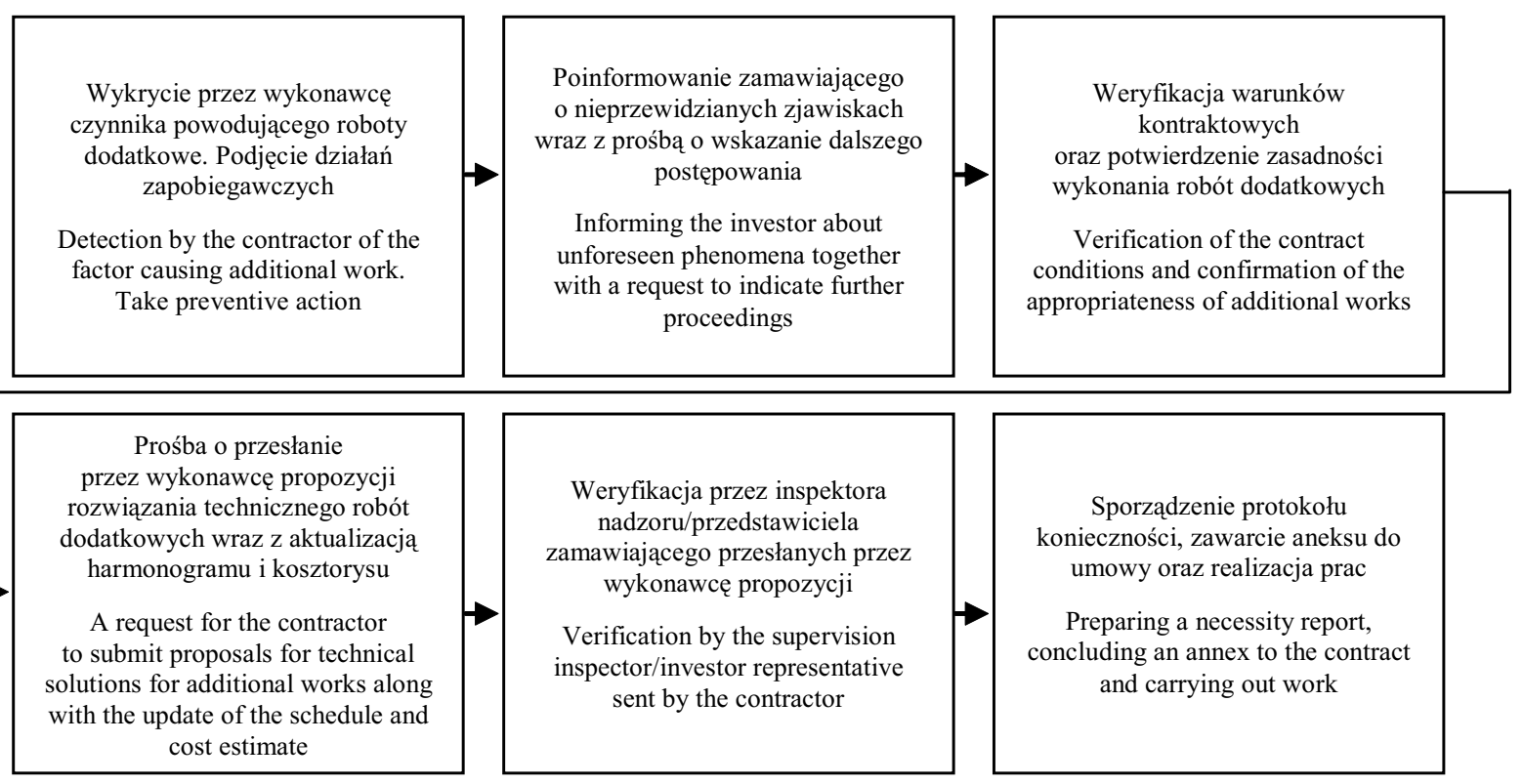

Rys. 4. Schemat zgłaszania robót dodatkowych przez wykonawcę w pozostałych projektach w ramach Krajowego Programu Kolejowego

Fig. 4. Schedule for submitting additional works by the contractor as part of other projects under the National Railway Programme 
będące najczęściej wystąpienia robót dodatkowych z uwzględnieniem ich podziału na etap projektowania oraz etap budowy. Autorzy przedstawili w pracy podstawowe uwarunkowania i zależności charakteryzujące zjawisko robót dodatkowych w ramach projektów objętych KPK. Prawidłowość przebiegu procesu wprowadzania robót dodatkowych do realizowanych inwestycji wymaga od wykonawcy znajomości wielu uwarunkowań: przepisów prawnych, charakterystyki branżowej czy też indywidualnych cech przedsięwzięcia. W artykule zwrócono także uwagę na konieczność przygotowania przez zamawiającego odpowiedniego zabezpieczenia finansowego. Potrzeba wprowadzenia robót dodatkowych podczas realizacji przedsięwzięć kolejowych występuje stosunkowo często, dlatego też autorzy w kolejnych pracach badawczych zamierzaja przeprowadzić badania ilościowe i dokonać oceny ryzyka robót dodatkowych w przedsięwzięciach kolejowych.

\section{PIŚMIENNICTWO}

Boczek, J. Z. (2015). Realizacja inwestycji budowlanych w systemie zamówień publicznych oraz procedury FIDIC. Szczecin: Wydawnictwo Euroinstytut.

Czemplik,A.(2003). Prawdopodobieństwowystąpieniarobot dodatkowych w przedsięwzięciu budowlanym. W Konferencja naukowa „Zarzadzanie przedsiębiorstwem budowlanym", Lublin - Kazimierz Dolny (strony 75-78). Lublin: Instytut Budownictwa i Architektury.

Czemplik, A. (2012). Zarządzanie procesem budowlanym z uwzględnieniem ryzyka robót dodatkowych. Archiwum Instytutu Inżynierii Ladowej, 13, 45-50.

Gładysz, B., Kuchta, D., Skorupka, D. i Duchaczek, A. (2015). Fuzzy analysis of project duration in situations of risk. AIP Publishing, 1648 (1), \#600003. https://doi. org/10.1063/1.4912835

Grzyl, B., Miszewska-Urbańska, E. i Apollo, M. (2017). Building Information Modelling as an Opportunity and Risk for Stakeholders Involved in Construction Investment Process. Procedia Engineering, 196, 1026-1033.

Hoła, B. (2015). Identification and evaluation of processes in a construction enterprise. Archives of Civil and Mechanical Engineering, 15 (2), 419-426.

Hoła, B. i Szóstak, M. (2015). Analysis of the state of the accident rate in the construction industry in European Union countries. Archives of Civil Engineering, 61 (4), 19-34.
Juszczyk, M., Leśniak, A. i Zima, K. (2013). Zamówienia na roboty dodatkowe w drogowych inwestycjach publicznych. Magazyn Autostrady, 7, 60-63.

Juszczyk, M., Leśniak, A. i Zima, K. (2018). ANN based approach for estimation of construction costs of sports fields. Complexity, 1-11. https://doi. org/10.1155/2018/7952434

Kaczorek, K., Krzemiński, M. i Ibadov, N. (2017). The problem of choosing risk management methodology at the example of railway construction. MATEC Web of Conferences, 117, 1-8. https://doi.org/10.1051/matecconf $/ 201711700073$

Kapliński, O. (2018). Innovative solutions in construction industry. Review of 2016-2018 events and trends. Engineering Structures and Technologies, 10 (1), 27-33.

Kowalski, J. i Połoński, M. (2018). Identification of risk investment using the risk matrix on railway facilities. Open Engineering, 8 (1), 506-512.

Krzemiński, M. (2017). Optimization of work schedules executed using the flow shop model, assuming multitasking performed by work crews. Archives of Civil Engineering, 63 (4), 3-19.

Lendo-Siwicka, M., Pawluk, K., Żerek, P. i Trach, R. (2018). The settlements of the changes introduced on the infrastructure investment contract based on the FIDIC contract conditions - case study. Scientific Review - Engineering and Environmental Sciences, 27 (3), 387-398.

Leśniak, A. i Juszczyk, M. (2018). Prediction of site overhead costs with the use of artificial neural network based model. Archives of Civil and Mechanical Engineering, 18 (3), 973-982. doi:10.1016/j.acme.2018.01.014

Leśniak, A., Piskorz, G., Spišáková, M. i Mačková, D. (2018). Causes of delays in construction works resulting from the provisions of the contract in Poland and Slovakia. Scientific Review - Engineering and Environmental Sciences, 27 (1), 71-81.

Ministerstwo Infrastruktury (2008). Master plan dla transportu kolejowego w Polsce do 2030 roku. Załącznik do Uchwały nr 277 Rady Ministrów z dnia 19 grudnia 2008 r. Warszawa. Pobrano z lokalizacji http://mib.bip.gov.pl/ fobjects/download/90069/master_plan_transport_kolejowy-pdf.html

Plebankiewicz, E., Zima, K. i Wieczorek, D. (2016). Life cycle cost modelling of buildings with consideration of the risk. Archives of Civil Engineering, 62 (2), 149-166.

Połoński, M. (2008). Wiadomości ogólne o procesie inwestycyjnym w budownictwie. W M. Połoński (red.), Proces inwestycyjny $i$ eksploatacja obiektów budowlanych (strony 9-26). Warszawa: Wydawnictwo SGGW. 
Polskie Koleje Państwowe Polskie Linie Kolejowe S.A. [PKP] (2017a). Raport roczny PKP Polskie Linie Kolejowe S.A. za 2016 rok. Pobrano z lokalizacji https:// www.plk-sa.pl/files/public/raport_roczny/Raport_ roczny_za_2016_caly_15.01.2018.pdf

Polskie Koleje Państwowe Polskie Linie Kolejowe S.A. [PKP] (2017b). Statut sieci kolejowej. Załącznik do uchwały Nr 1177/2017 Zarządu PKP Polskie Linie Kolejowe S.A. z dnia 05 grudnia 2017 r. Pobrano z lokalizacji https://www.plk-sa.pl/files/public/user_upload/ pdf/Statut_Sieci_Kolejowej/17.05.2019/Statut_sieci_ kolejowej_11_29_popr_IBZ.PDF

Sobotka, A. i Czarnigowska, A. (2005). Analysis of supply system models for planning construction project logistics. Journal of Civil Engineering and Management, 11(1), 73-82.

Uchwała nr 186/2017 Rady Ministrów z dnia 4 grudnia
2017 r. zmieniająca uchwałę $\mathrm{w}$ sprawie ustanowienia Krajowego Programu Kolejowego do 2023 roku.

Uchwała nr 219/2011 Rady Ministrów z dnia 7 listopada 2011 r. - w sprawie ustanowienia Wieloletniego Programu Inwestycji Kolejowych do 2013 roku z perspektywą do roku 2015.

Ustawa z dnia 23 kwietnia 1964 r. - Kodeks cywilny. Dz.U. $1964 \mathrm{nr} 16$, poz. 93 z późn. zm.

Ustawa z dnia 29 stycznia 2004 r. - Prawo zamówień publicznych. Dz.U. 2004 nr 19, poz. 177 z późn. zm.

\section{ADDITIONAL WORKS IN RAILWAY CONSTRUCTION PROJECTS}

\section{ABSTRACT}

The aim of the work is to analyse the specificity of the occurrence of additional works in railway construction projects currently carried out in Poland. The article presents the key elements of additional works: the definition of the phenomenon, the factors causing their occurrence, the way of implementing additional works to the basic contract and the expected consequences of additional works. The most important legal conditions were discussed, including the amendment to the Public Procurement Law of 22 June 2016. The authors presented proposals for schemes for reporting additional works in the most common types of investment implementation depending on the applied contract type.

Key words: additional works, railway investments, public procurement 